\title{
Handlingsplanen - kort oppsummert
} Intervju med Anette Mjelde, avdelingsdirektør i Helsedirektoratet

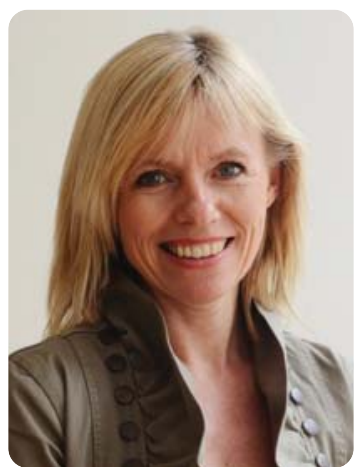

Anette Mjelde

\section{Hva er de viktigste satsings- områdene og hvorfor?}

- Handlingsplanen for forebygging av selvmord og selvskading 2014-2017 lanserer 29 tiltak og viderefører allerede pågående arbeid i planperioden. Det er tiltak for å sikre god psykisk helse og mestring i befolkningen, redusere forekomsten av selvmord og selvskading i risikogrupper, sikre god oppfølging og ivaretakelse av etterlatte, pårørende og andre berørte. Der er også tiltak for å sikre at tjenesteapparatet og strategiene som utvikles er kunnskapsbaserte, som også er viktig i arbeidet framover. Handlingsplanen legger et økt fokus på forebygging og tidlig intervensjon, sammenlignet med tidligere handlingsplan. Det er også nytt at planen tematiserer forebygging av selvskading.

Prosessen fram mot ferdig handlingsplan - hvordan har den vaert?

- Det har vært en lang og tidvis krevende prosess, hvor direktoratet har vært i tett samarbeid med brukerorganisasjoner og kunnskaps- og kompetansemiljøer på feltet. Vi er nå glade for at handlingsplanen er lansert, og ser fram til et godt samarbeid på feltet i årene framover.

\section{Hvordan vil dere sørge for at det blir finansiert?}

- Helse- og omsorgsdepartementet bevilget 5 millioner kroner til tiltakene ved lansering av handlingsplanen i 2014. Videre finansiering har departementet sagt skal avgjøres i de årlige budsjettene fremover.

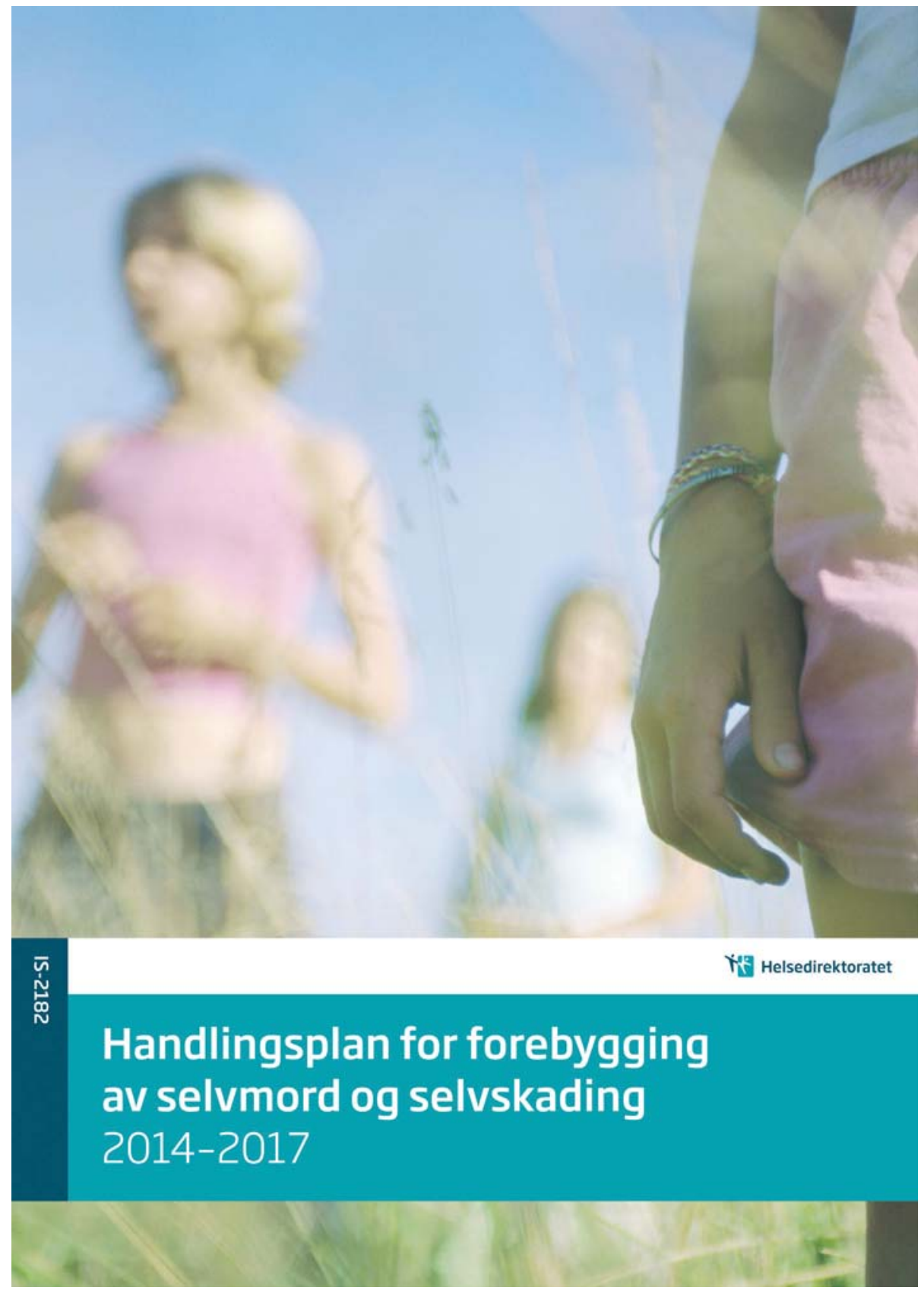

Planen kan utvides med nye tiltak i planperioden, i tråd med føringer i statsbudsjettet og Helse- og omsorgsdepartementets årlige tildelingsbrev til Helsedirektoratet.

\section{Hva skjer nå?}

- Handlingsplanen viderefører allerede pågående arbeid innen det selvmordsforebyggende feltet, og Helsedirektoratet har gitt tilskudd til ulike selvmordsforebyg- gende tiltak på i overkant av 17 millioner kroner for å videreføre dette arbeidet i 2014. I tillegg vil Helsedirektoratet igangsette en rekke nye tiltak i årene framover, og vi er nå i en prosess for å vurdere hvordan de nye midlene ( 5 millioner kroner) som er øremerket til tiltakene i handlingsplanen skal fordeles i 2014.

Intervju ved Hanne Holmesland 